\title{
ANTIBACTERIAL NANOCOMPOUND BASED ON SILICONE RUBBER. PART II - BIOLOGICAL CHARACTERISATION
}

\author{
Mihaela NITUICĂ (VîLSAN) ${ }^{1 *}$, Maria SÖNMEZ ${ }^{1}$, Mihai GEORGESCU ${ }^{1}$, Maria Daniela STELESCU닌 ${ }^{1}$, Laurenţia \\ ALEXANDRESCU ${ }^{1}$, Dana GURĂU ${ }^{1}$, Carmen CURUTIU ${ }^{2,3}$, Lia Maria DITU ${ }^{2,3}$
}

${ }^{1}$ INCDTP - Division Leather and Footwear Research Institute, 93 Ion Minulescu St., sector 3, Bucharest, mihaela.nituica@icpi.ro,mihaelavilsan@yahoo.com

${ }^{2}$ University of Bucharest, Faculty of Biology, 1-3 Portocalelor St., 6th district, 060101, Bucharest, Romania

${ }^{3}$ Research Institute of University of Bucharest, 36-46 M. Kogalniceanu St., 5th district, 050107, Bucharest, Romania

Received: 22.07.2019

Accepted: 27.11.2019

https://doi.org/10.24264/Ifj.19.4.7

\section{ANTIBACTERIAL NANOCOMPOUND BASED ON SILICONE RUBBER. PART II - BIOLOGICAL CHARACTERISATION}

ABSTRACT. The aim of this work is to characterize an antibacterial polymeric nanocompound based on silicone elastomer (silicone rubber), reinforced with TiO2 nanoparticles, crosslinked with dicumyl peroxide (PD). The antibacterial polymer nanocompound was obtained by vulcanization on a laboratory roll (vulcanization is a main step, with a major impact on the final properties of the products), in the form of a 3-5 $\mathrm{mm}$ sheet, in order to be biologically characterized, as well as physico-mechanically and morpho-structurally characterized, according to the standards in force, in specific environments for the food and pharmaceutical fields. Vulcanized silicone elastomers have uses in the food, medical, pharmaceutical industries, etc., because they do not contain substances that are not toxicologically admitted. The dispersion of TiO2 nanopowders (with antifungal, antibacterial and antimicrobial properties) in the nanocompound mass has a decisive role in influencing its antimicrobial and antibacterial sterilization properties. The polymeric nanocompound based on silicone rubber contributes to improving the quality of the products, but also to environmental protection and, of course, protection of human health.

KEY WORDS: biological characterisation, antibacterial nanocompound, silicone rubber, nanoparticles

NANOCOMPOUND ANTIBACTERIAN PE BAZĂ DE CAUCIUC SILICONIC. PARTEA II - CARACTERIZARE BIOLOGICĂ

REZUMAT. Scopul acestei lucrări este caracterizarea unui nanocompound polimeric antibacterian pe bază de elastomer siliconic (cauciuc siliconic), ranforsat cu nanoparticule de TiO2, reticulat cu peroxid de dicumil (PD). Nanocompoundul polimeric antibacterian a fost obţinut prin vulcanizare pe un valţ de laborator (vulcanizarea este o etapă principală, cu un impact major asupra proprietăţilor finale ale produselor), sub forma unei foi de 3-5 mm, pentru a putea fi supus caracterizării biologice, dar şi caracterizărilor fizico-mecanice şi morfo-structurale, conform standardelor în vigoare în medii specifice domeniilor alimentar şi farmaceutic. Vulcanizatele din elastomer siliconic au utilizări în domeniul alimentar, medical, farmaceutic etc., deoarece nu conţin substanţe care nu sunt admise din punct de vedere toxicologic. Dispersarea nanopulberilor de TiO2 (cu proprietăţi antifungice, antibacteriene şi antimicrobiene) în masa nanocompoundului au un rol determinant în influenţarea proprietăţilor de sterilizare antimicrobiană şi antibacteriană a acestuia. Nanocompoundul polimeric pe bază de cauciuc siliconic contribuie la îmbunătăţirea calităţii produselor, dar şi la protecţia mediului şi, bineînţeles, a sănătăţii omului.

CUVINTE CHEIE: caracterizare biologică, nanocompound antibacterian, cauciuc siliconic, nanoparticule

NANOCOMPOSITE ANTIBACTÉRIEN À BASE DE CAOUTCHOUC DE SILICONE. PARTIE II - CARACTÉRISATION BIOLOGIQUE

RÉSUMÉ. Le but de cet article est de caractériser un nanocomposite polymère antibactérien à base d'élastomère de silicone (caoutchouc de silicone), renforcé de nanoparticules de $\mathrm{TiO}_{2}$, réticulé au peroxyde de dicumyle (PD). Le nanocomposite polymère antibactérien a été obtenu par vulcanisation sur un rouleau de laboratoire (la vulcanisation est une étape principale ayant un impact majeur sur les propriétés finales des produits), sous la forme d'une feuille de 3 à $5 \mathrm{~mm}$, afin d'être caractérisé du point de vue biologique, mais aussi physico-mécanique et morpho-structurel, selon les normes en vigueur dans des environnements spécifiques pour les domaines alimentaire et pharmaceutique. Les élastomères de silicone vulcanisés ont des utilisations dans les domaines alimentaire, médical, pharmaceutique, etc., car ils ne contiennent pas de substances qui ne sont pas toxicologiquement admises. La dispersion de nanopoudres de TiO2 (aux propriétés antifongiques, antibactériennes et antimicrobiennes) dans la masse de nanocomposites joue un rôle déterminant dans l'influence de ses propriétés de stérilisation antimicrobiennes et antibactériennes. Le nanocomposite polymère à base de caoutchouc silicone contribue à l'amélioration de la qualité des produits, mais également à la protection de l'environnement et, bien sûr, de la santé humaine.

MOTS-CLÉS : caractérisation biologique, nanocomposite antibactérien, caoutchouc de silicone, nanoparticules 


\section{INTRODUCTION}

Silicone elastomers are polymers with special characteristics due to their high resistance to temperatures from $-100^{\circ} \mathrm{C}$ to above $+300^{\circ} \mathrm{C}[1,2]$. These are high temperatures specific to sterilization, used to make products for the food, pharmaceutical and medical industries. Items made of silicone elastomers (silicone rubber) are preferred in medicine and pharmaceutical products because they do not contain substances such as antioxidants and other restricted ingredients [3-6].

Staphylococcus (S.) aureus (as a model for Gram-positive bacteria), Escherichia (E.) coli (prototype for Gram-negative bacteria) and Candida albicans (as a representative of fungi) are among the most commonly isolated in clinics, with an increased incidence in nosocomial infections. In addition, antibiotic resistance in these strains, namely MRSA strains (methicillinresistant Staphylococcus aureus) and E. coli ESBL strains (extended spectrum beta lactamase), pose major problems in the therapeutic approach $[7,8]$. One solution in this regard may be the development of new materials coated with various nanoparticles in order to inhibit bacterial adhesion to the substrate, thus eliminating their chance of triggering an infectious process. Antibacterial activity of nanoparticles has been intensely studied recently. Escherichia coli is the most prevalent facultative anaerobic species from the gastrointestinal tract of human and animals, so a commensal species, but is also one of the most involved bacteria in medical conditions, causing a number of significant illnesses. Antibiotic resistance in Escherichia coli is a great concern because it is one the most common Gram-negative pathogen, and the number of resistant strains is increasing, most of them being Escherichia coli ESBL (extended spectrum beta lactamase) strains [9-11]. Pseudomonas aeruginosa is also an important pathogen especially in immunocompromised patients, with an intrinsic resistance to many antibiotic classes, and a high capacity to develop biofilms (microbial cells associated between them and from a substrate enclosed in an extracellular polymeric matrix secreted by them), in which microorganisms are safe from antibiotic treatment becoming more resistant and capable to determine persistent infections [11-15].

In the medical field, all indwelling prosthetic devices such as catheters, heart valves, ocular lenses, but also all the surfaces from medical units are predisposed to be colonized by biofilms. Staphylococcus aureus is another most frequent species that causes nosocomial infections and biofilm associated infections on indwelling medical devices.

Although fungal biofilms have not received so much attention comparing with bacterial ones, some conditions such as immunosuppression, the prolonged use of indwelling devices, high periods of hospitalization increased the prevalence of fungal disease, most commonly associated with infections being Candida albicans, responsible for both superficial and systemic disease [9-11].

This paper presents the development of polymer nanocompounds based on Elastosil R701/70-OH (silicone rubber) [16-18] reinforced with $\mathrm{TiO}_{2}$ - nanometric particles (with antifungal, antibacterial and antimicrobial properties), filled with $\mathrm{CaCO}_{3}$ (chalk), with stearin as plasticizer and crosslinked with PD - dicumyl peroxide reinforced, which were biologically characterized in specific environments for the pharmaceutical and food industries according to standards in force.

\section{EXPERIMENTAL}

\section{Materials}

The following materials were used to make the antibacterial polymer nanocompound:

(1) Elastosil R701/70-OH - silicon rubber: polydimethylsiloxane with vinyl groups, dynamic viscosity over $9.000 .000 \mathrm{mPa} * \mathrm{~s}$, in the form of paste, density $-1.32 \mathrm{~g} / \mathrm{cm}^{2}$, colour - opaque;

(2) stearin, white flakes, moisture $-0.5 \%$ max, ash $-0.025 \%$ max;

(3) ZnO - zinc oxide microparticles: precipitate $93-95 \%$, in the form of white powder, density $-5.5 \mathrm{~g} / \mathrm{cm}$, specific surface $-45-55 \mathrm{~m}^{2} / \mathrm{g}$;

(4) $\mathrm{TiO}_{2}$ - titanium dioxide nanoparticles: white nanopowder, assay $\geq 99.5 \%$ trace metals basis; 
(5) chalk: $\mathrm{CaCO}_{3}$ precipitate - white powder, molecular weight 100.09;

(6) PD - di(tert-butylperoxyisopropyl) benzene: powder $40 \%$ with calcium carbonate and silica - Perkadox 14-40B (1.65 g/ $\mathrm{cm}^{3}$ density, 3.8\% active oxygen content, $\mathrm{pH} \mathrm{7,} \mathrm{assay:} \mathrm{39.0-41.0 \% ).}$

For the antibacterial tests the following were used:

(1) Staphylococcus aureus ATCC 25923;

(2) Escherichia coli ATCC 25992;

(3) Candida albicans ATCC 1023, and were preserved on glycerol medium, seeded on nutrient gelatin agar medium and Sabouraud with chloramphenicol (for Candida), respectively, to obtain $24 \mathrm{~h}$ cultures.

\section{Methods}

\section{Composites Processing}

The antibacterial polymer nanocompound based on elastomer (silicone rubber - Elastosil R701/70-OH), reinforced with $\mathrm{TiO}_{2}$ - nanometric particles, filled with $\mathrm{CaCO}_{3}$ (chalk) and crosslinked with PD - dicumyl peroxide was developed by electric laboratory roll mill mixing and the rolls were water-cooled. The Elastosil R701/70-OH (silicone rubber) was plasticized between the rolls for approximately 3 minutes, the stearin (plasticizer) was added and mixing continued for 1.5 minutes; the microparticle of zinc oxide was then added and embedded into the mixture until homogenisation; $\mathrm{TiO}_{2}$ nanoparticles were added, continuing to mix for 3 minutes until the nanometric component was embedded; the $\mathrm{CaCO}_{3}$ filler was then added and mixing continued for 2.5 minutes and the dicumyl peroxide (last ingredient) is embedded into the mixture for 2 minutes. After adding all the ingredients, the mixture is homogenized on the roll mill for maximum 3 minutes and taken off in the form of a 3-4 $\mathrm{mm}$ thick sheet. The order of adding ingredients was strictly observed, according to Table 1. The nanocompound resulting after $24 \mathrm{~h}$ stabilization at room temperature was biologically, physico-mechanically, chemically and morpho-structurally characterized according to standards in force.

Analysis and dosing of raw materials

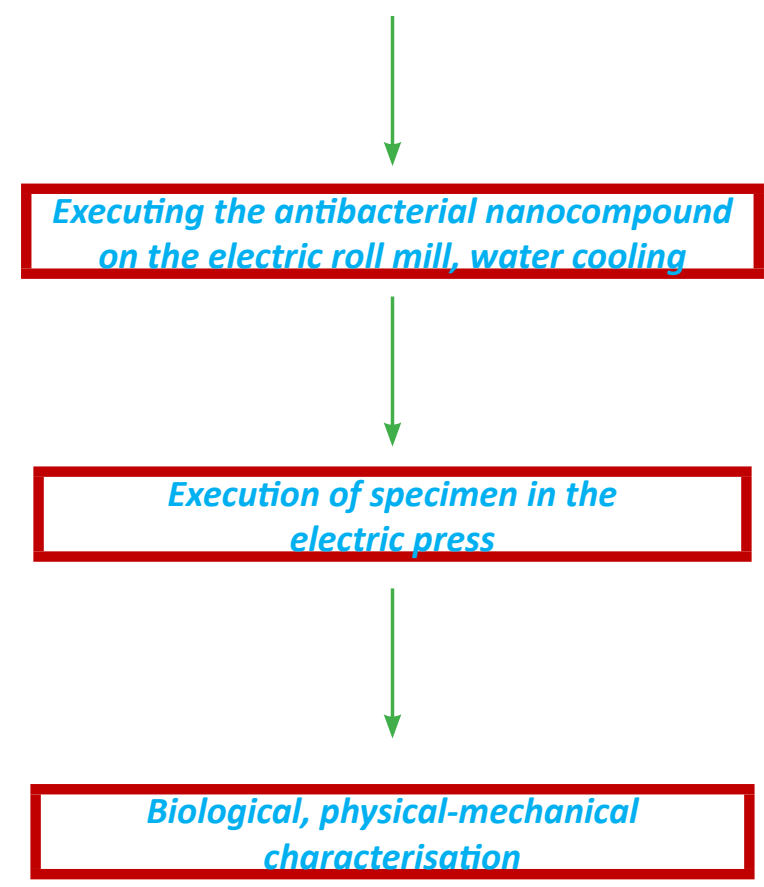

Figure 1. Technological process for obtaining the antibacterial elastomeric nanocompound reinforced with $\mathrm{TiO}_{2}$ nanoparticles [19] 
Table 1: Formulations of antibacterial polymer nanocompounds based on silicone rubber reinforced with $\mathrm{TiO}_{2}[19]$

\begin{tabular}{cccccc}
\hline Component & $\mathrm{MU}$ & $\begin{array}{c}\mathrm{CS}_{1} \\
\text { (control) }\end{array}$ & $\mathrm{P}_{5}$ & $\mathrm{P}_{6}$ & $\mathrm{P}_{7}$ \\
\hline Silicone rubber & $\mathrm{g}$ & 150 & 150 & 150 & 150 \\
Stearin & $\mathrm{g}$ & 7.5 & 7.5 & 7.5 & 7.5 \\
Zinc oxide (microparticles) & $\mathrm{g}$ & 6 & 4.5 & 3 & 1.5 \\
Titanium dioxide (nanoparticles) & $\mathrm{g}$ & - & 1.5 & 3 & 4.5 \\
Chalk (CaCO $)$ & $\mathrm{g}$ & 15 & 15 & 15 & 15 \\
$\mathrm{PD}$ (dicumyl peroxide $-40 \%$ - on silica and $\mathrm{CaCO}_{3}$ substrate) & $\mathrm{g}$ & 11.25 & 11.25 & 11.25 & 11.25 \\
\hline
\end{tabular}

\section{Biologic Setup}

Staphylococcus aureus ATCC 25923, Escherichia coli ATCC 25992 and Candida albicans ATCC 10231 strains from the American Type Culture Collection (ATCC, US), stored on glycerol medium, were seeded on nutrient gelatin agar medium and Sabouraud with chloramphenicol (for Candida), respectively to obtain $24 \mathrm{~h}$ cultures that were further used in the experiment.

The sterilized samples were placed in sixwell plates (Nunc) with $2 \mathrm{ml}$ broth (Sabouraud, respectively) and $200 \mu \mathrm{l}$ microbial suspension with 0.5 McFarland density ( $1.5 \times 108$ CFU/ $\mathrm{mL}$ ) for bacteria and 1 McFarland density for fungi $(3 \times 108 \mathrm{CFU} / \mathrm{ml})$. After $24 \mathrm{~h}$ incubation at $37^{\circ} \mathrm{C}$ the colonized materials were washed with sterile distilled water to remove non-adherent microorganisms and introduced into Eppendorf tubes with $1 \mathrm{ml}$ sterile saline (AFS), sonicated for $15 \mathrm{~s}$ at maximum power and then vortexed for $15 \mathrm{~s}$ at 3000 rotations $/ \mathrm{min}$. From the suspension recovered in AFS, decimal dilutions were performed, which were seeded in triplicate (3 replicates of $10 \mu \mathrm{l}$ each) on nutrient gelatin medium (and Sabouraud with chloramphenicol, respectively) to calculate the number of UFC (colony forming units)/ml.

\section{RESULTS AND DISCUSSIONS}

\section{Biological Characterization of Antibacterial Polymer Nanocompounds}

In recent years, the antibacterial activity of nanoparticles and many surfaces coated with nanoparticles has been intensively studied, therefore a solution in this regard was the development and use of new materials with different types of nanoparticles to inhibit bacterial adhesion to surfaces, thus eliminating the possibility of triggering an infectious process.

In this study, the antimicrobial activity of some polymeric antimicrobial nanocompound surfaces based on silicone rubber, reinforced with $\mathrm{TiO}_{2}$ nanoparticles (with antifungal, antibacterial and antimicrobial properties) and cross-linked with dicumyl peroxide (Percadox - PD) is tested. The antibacterial polymer nanocompounds were tested and characterized according to standard ASTM: E 2149-10. The samples were tested for $24 \mathrm{~h}$ with the above mentioned strains: Staphylococcus aureus ATCC 25923; Escherichia coli ATCC 25992; Candida albicans ATCC 1023, Figures 2-4.

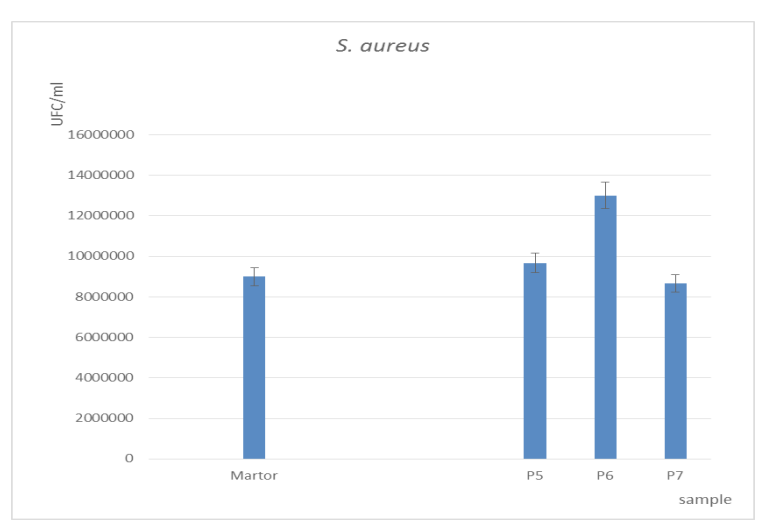

Figure 2. Biological characterization of samples with $\mathrm{TiO}_{2}$ nanoparticles on Staphylococcus aureus ATCC 25923 strains

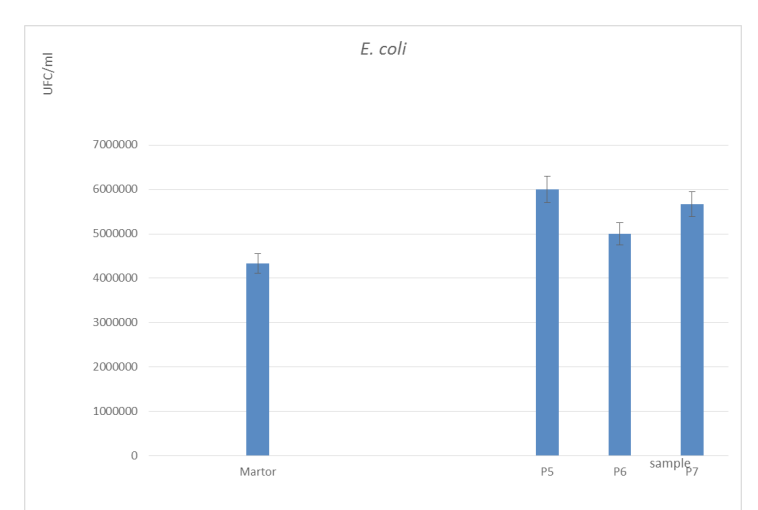

Figure 3. Biological characterization of samples with $\mathrm{TiO}_{2}$ nanoparticles on Escherichia coli ATCC 25992 strains 


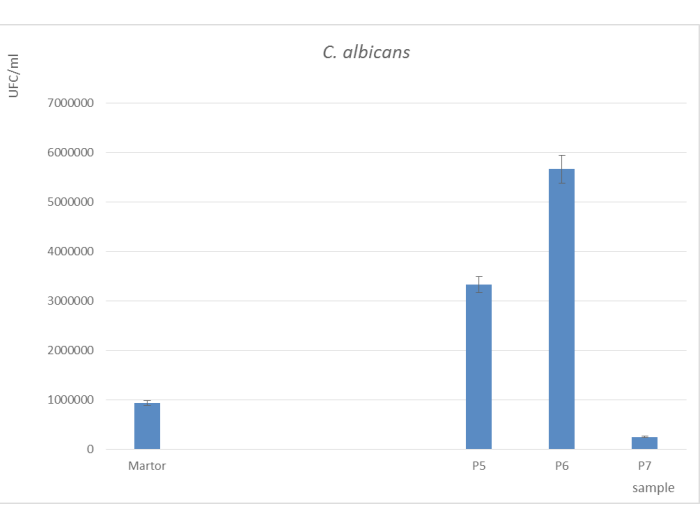

Figure 4. Biological characterization of samples with $\mathrm{TiO}_{2}$ nanoparticles on Candida albicans ATCC 10231 strains

The results showed that the materials treated with nanoparticles show an inhibition adhesion capacity compared to the control sample, except for $E$. coli for which the results were not significantly different. The effect was dependent on bacterial strains and also on the concentration of $\mathrm{TiO}_{2}$ nanoparticles introduced into the polymeric compound.

P7 samples have been shown to be very effective especially against fungus species Candida albicans, but also against gram positive bacteria - Staphylococcus aureus, compared to the control sample.

In the case of Escherichia coli strains, P7 and P5, P6 showed no antimicrobial activity (against this strain), it rather seems that a small amount of $\mathrm{TiO}_{2}$ favours bacterial adhesion, as the UFC values are higher than those of the control sample.

\section{CONCLUSIONS}

This paper presents the development of polymer nanocompounds based on Elastosil R701/70-OH (silicone rubber), reinforced with $\mathrm{TiO}_{2}$ - nanometric particles (with antifungal, antibacterial and antimicrobial properties), filled with $\mathrm{CaCO}_{3}$ (chalk), with stearin as plasticizer and crosslinked with PD - dicumyl peroxide reinforced, which were biologically characterized in specific environments for the pharmaceutical and food industries according to standards in force.

The antibacterial polymer nanocompounds were tested and characterized according to standard ASTM: E 2149-10. Samples were tested for $24 \mathrm{~h}$, using the following strains: Staphylococcus aureus ATCC 25923; Escherichia coli ATCC 25992; Candida albicans ATCC 1023.

Due to the high temperature resistance properties, above $+300^{\circ} \mathrm{C}$, specific for the sterilization operation and the use of $\mathrm{TiO}_{2}$ nanoparticles, with antimicrobial, antibacterial and antifungal role, polymeric nanocomposites can be used in the food and pharmaceutical industry.

As a result of biological characterization, the P7 sample was selected as having potential applications in the food and pharmaceutical industry.

\section{Acknowledgements}

This research was financed by ANCSI through 6PFE/2018 - PERFORM-TEX-PEL and NUCLEU Program 2016-2017, project code PN 163401 10: "Antibacterial compound based on silicone rubber and $\mathrm{ZnO}$ and $\mathrm{TiO} 2$ nanoparticles processed by vulcanization", contract no. 26N/2016.

\section{REFERENCES}

1. Fallahi, D., Mirzadeh, H., Khorasani, M.T., Physical, mechanical, and biocompatibility evaluation of three different types of silicone rubber, J Appl Polym Sci, 2003, 8, 2522-2529, https://doi.org/10.1002/app.11952.

2. Hanke, B., Bort, F., Anti-microbial silicone rubber composition and method for making same, US Patent 6,822,034 B2, 23 November 2004.

3. Shi, F., Clayman, R., Louie, M.K., Lin, Y.H., Lin, Y.C., Silicone composition and devices incorporating same, US Patent 8,257,827 B1, 4 September 2012.

4. Dobrinescu, A., New types of elastomers for special purposes, Ministry of Light Industry, Centre for Documentation and Technical Publications, Bucharest, 1971.

5. Volintiru, T., Ivan, Gh., Technological bases of processing elastomers, Technical Press, Bucharest, 1974. 
6. Mirici, L.E., Thermoplastic Elastomers, Art. Press \& Augusta, Timisoara, 2005.

7. Zhou, H., Wang, H., Niu, H., Gestos, A., Wang, $X$., Lin, T., Fluoroalkyl silane modified silicone rubber/nanoparticle composite: a super durable, robust superhydrophobic fabric coating, Adv Mater, 2012, 24, 2409-2412, https://doi.org/10.1002/adma.201200184.

8. Hron, P., Slechtova, J., Smetana, K., Dvorankova, B., Lopour, P., Silicone rubber-hydrogel composites as polymeric biomaterials. IX. Composites containing powdery polyacrylamide hydrogel, Biomaterials, 1997, 18, 15, 10691073, https://doi.org/10.1016/S01429612(97)00039-2.

9. Friedman, N.D., Kaye, K.S., Stout, J.E., McGarry, S.A., Trivette, S.L., Briggs, J.P. et al., Health care-associated bloodstream infections in adults: a reason to change the accepted definition of community-acquired infections, Ann Intern Med, 2002, 137, 7917, https://doi.org/10.7326/0003-4819-13710-200211190-00007.

10. ASTM: E 2149-10, "Standard test methods for determinung the antimicrobial activity of immobilizes antimicrobial agents under dynaic contacts condition".

11. JIS Z 2801:2006, "Antimicrobial products - test for antimicrobial activity and efficacy".

12. Chandra, J., Kuhn, D.M., Mukherjee, P.K., Hoyer, L.L., McCormick, T., Ghannoum, M.A., Biofilm Formation by the Fungal Pathogen Candida albicans: Development, Architecture, and Drug Resistance, J Bacteriol, 2001, 183, 18, 5385-5394, PMCID: PMC95423, https:// doi.org/10.1128/JB.183.18.5385-5394.2001.

13.Otto, M., Staphylococcal Biofilms, Curr Top Microbiol Immunol, 2008, 322, 207-228, https:// doi.org/10.1007/978-3-540-75418-3_10.

14. Nituica, M., Sonmez, M., Stelescu, M.D., Gurau, D., Curutiu, C., Ditu, L.M., Polymer nanocomposite based on silicone rubber reinforced with nanoparticles processed by vulcanization, University Politehnica of Bucharest, Sci Bull B Chem Mater Sci, 2017, 79, 4, 63-72, ISSN:1454-2331, Accession Number: WOS:000424134600007

15. Nituica, M., Pantazi, M., Vasilescu, A.M., Curutiu, C., Ditu, L.M., Cured antibacterial compounds based on silicone elastomer reinforced with nanoparticles, 17th International Multidisciplinary Scientific Geoconference, SGEM 2017, Albena, Bulgaria, 29 June - 5 July 2017, 17, 61, 81-88, http;//doi.org/10.5593/sgem2017/61.

16. Stelescu, M.D., Characteristics of silicone rubber blends, Leather and Footwear Journal, 2010, 10, 3, 51-58.

17. Mashak, A., In vitro drug release from silicone rubber-polyacrylamide composite, Silicon Chem, 2008, 3, 6, 295-301, https:// doi.org/10.1007/s11201-007-9031-1.

18. Malcolm, K., Woolfson, D., Russell, J., Tallon, P., Mc Auley, L., Craig, D., Influence of silicone elastomer solubility and diffusivity on the in vitro release of drug from intravaginal rings, J Control Release, 2003, 90, 2, 217-225, https://doi.org/10.1016/S01683659(03)00178-0.

19. Nituica (Vilsan), M., Sonmez, M., Georgescu, M., Gurau, D., Niculescu, O., Antibacterial nanocompound based on silicone rubber. Part I - Obtaining and characterisation, Leather and Footwear Journal, 2017, 17, 1, 39-44, https://doi. org/10.24264/Ifj.17.1.5.

(C) 2019 by the author(s). Published by INCDTPICPI, Bucharest, RO. This is an open access article distributed under the terms and conditions of the Creative Commons Attribution license (http://creativecommons.org/licenses/by/4.0/). 